\title{
Performance Assessment of the Proposed Monitored Retrievable Storage Facility
}
A. D. Chockie
C. J. Hostick
C. Winter

February 1986

Prepared for the U.S. Department of Energy under Contract DE-AC06-76RLO 1830

Pacific Northwest Laboratory Operated for the U.S. Department of Energy by Battelle Memorial Institute 


\title{
DISCLAIMER
}

This report was prepared as an account of work sponsored by an agency of the United States Government. Neither the United States Government nor any agency thereof, nor any of their employees, makes any warranty, express or implied, or assumes any legal liability or responsibility for the accuracy, completeness, or usefulness of any information, apparatus, product, or process disclosed, or represents that its use would not infringe privately owned rights. Reference herein to any specific commercial product, process, or service by trade name, trademark, manufacturer, or otherwise, does not necessarily constitute or imply its endorsement, recommendation, or favoring by the United States Government or any agency thereof. The views and opinions of authors expressed herein do not necessarily state or reflect those of the United States Government or any agency thereof.

\author{
PACIFIC NORTHWEST LABORATORY \\ operated by \\ BATTELLE \\ for the \\ UNITED STATES DEPARTMENT OF ENERGY \\ under Contract DE-AC06-76RLO 1830
}

\begin{tabular}{|c|c|}
\hline \multirow{3}{*}{\multicolumn{2}{|c|}{$\begin{array}{l}\text { Printed in the United States of America } \\
\text { Available from } \\
\text { National Technical Information Service }\end{array}$}} \\
\hline & \\
\hline & \\
\hline \multirow{2}{*}{\multicolumn{2}{|c|}{$\begin{array}{l}\text { United States Department of Commerce } \\
5285 \text { Port Royal Road }\end{array}$}} \\
\hline & \\
\hline \multicolumn{2}{|c|}{ Springfield, Virginia 22161} \\
\hline \multirow{2}{*}{\multicolumn{2}{|c|}{$\begin{array}{l}\text { NTIS Price Codes } \\
\text { Microfiche } A 01\end{array}$}} \\
\hline & \\
\hline \multicolumn{2}{|c|}{ Printed Copy } \\
\hline & Price \\
\hline Pages & Codes \\
\hline 001-025 & $\mathrm{A} 02$ \\
\hline 026-050 & A03 \\
\hline 051-075 & A04 \\
\hline 076-100 & A05 \\
\hline $101-125$ & $A 06$ \\
\hline $126-150$ & A07 \\
\hline 151.175 & $A 08$ \\
\hline $176-200$ & $\mathrm{~A} 09$ \\
\hline $201-225$ & A010 \\
\hline $226-250$ & A011 \\
\hline $251-275$ & A012 \\
\hline $276-300$ & \\
\hline
\end{tabular}



A. D. Chockie
C. J. Hostick
c. Winter

February 1986

Prepared for

the U.S. Department of Energy

under Contract DE-AC06-76RLO 1830

Pacific Northwest Laboratory

Richland, Washington 99352 


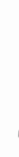

4

l. 


\section{EXECUTIVE SUMMARY}

Pacific Northwest Laboratory (PNL) has completed a performance evaluation of the proposed monitored retrievable storage (MRS) facility. This study was undertaken as part of the Department of Energy MRS Program at PNL. The objective of the performance evaluation was to determine whether the conceptual MRS facility would be able to process spent fuel at the specified design rate of 3600 metric tons of uranium (MTU) per year.

The performance of the proposed facility was assessed using the computer mode1 COMPACT (Computer Optimization of Processing and Cask Transport) to simulate facility operations.

The COMPACT model consisted of three application models each of which addressed a different aspect of the facility's operation:

- MRS/waste transportation interface

- cask handling capability

- disassembly/consolidation (hot cell) operations. Our conclusions, based on the assessment of design criteria for the proposed facility, are as follows:

- Facilities and equipment throughout the facility have capability beyond the $3600 \mathrm{MTU} / \mathrm{yr}$ design requirement. This added capability provides a reserve to compensate for unexpected perturbations in shipping or handing of the spent fuel.

- Calculations indicate that the facitity's maximum maintainable processing capability is approximately $4800 \mathrm{MTU} / \mathrm{yr}$. 
$+$

. 


\section{CONTENTS}

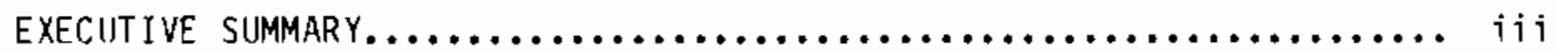

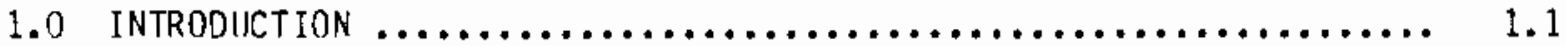

1.1 MRS FACILITY PERF ORMANCE MEASIJRES ................. 1.1

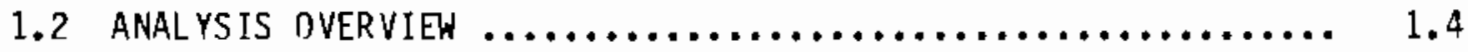

2.0 PERformance ASSESSMEnt MEthodology $\ldots \ldots \ldots \ldots \ldots \ldots \ldots \ldots \ldots \ldots \ldots \ldots$

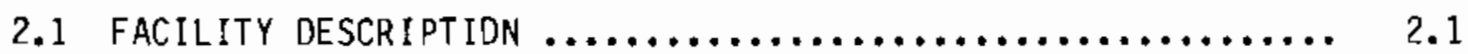

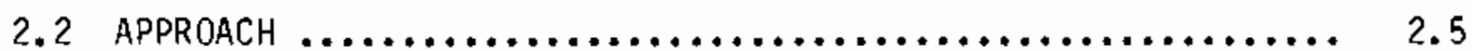

2.3 DESIGN EVALUATION MODELS $\ldots \ldots \ldots \ldots \ldots \ldots \ldots \ldots \ldots \ldots \ldots \ldots \ldots$

3.0 ASSESSMENT OF MRS FACILITY PERFORMANCE $\ldots \ldots \ldots \ldots \ldots \ldots \ldots \ldots \ldots \ldots . \ldots \ldots$

3.1 FACILITY OPERATING ASSUMPTIONS $\ldots \ldots \ldots \ldots \ldots \ldots \ldots \ldots \ldots \ldots \ldots$

3.2 Expected facility PERformance $\ldots \ldots \ldots \ldots \ldots \ldots \ldots \ldots \ldots \ldots \ldots . . \ldots \ldots$

3.2.1 Shipping Cask Turnaround Time ................ 3.2

3.2.2 Adequacy of Lag Storage Capacities $\ldots \ldots \ldots \ldots \ldots \ldots . . .6$

3.2.3 Equipment Perfomance ..................... 3.9

3.2.4 Throughput Capability .................... 3.12

3.3 IMPACT OF VARIATIONS IN ARRIVAL PATTERNS ON FACILITY

3.3.1 Variations in Truck/Rail Split ................ 3.13

3.3.2 Alternative Cask Capacities .................. 3.14

3.3.3 Arrival of Different Types of Spent Fuel
Assemblies $\ldots \ldots \ldots \ldots \ldots \ldots \ldots \ldots \ldots \ldots \ldots \ldots \ldots \ldots \ldots \ldots \ldots \ldots$

APPENOIX A - MODEL DESCRIPTION AND REQUIREMENTS ............... A. 1

APPENDIX B - OVERHEAD CRANE RELIABILITY ANALYSIS ............. B.

REFERENCES $\ldots \ldots \ldots \ldots \ldots \ldots \ldots \ldots \ldots \ldots \ldots \ldots \ldots \ldots \ldots \ldots \ldots \ldots \ldots \ldots \ldots \ldots \ldots \ldots \ldots$ 


\section{FIGIJRES}

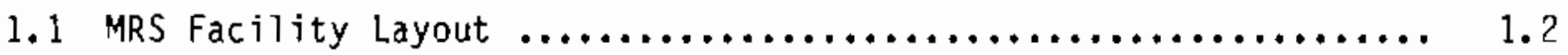

2.1 Integral Monitored Retrievable Storage Facility ............ 2.2

2.2 MRS Receiving and Handling Building $\ldots \ldots \ldots \ldots \ldots \ldots \ldots \ldots \ldots \ldots . . \ldots . \ldots . \ldots$

2.3 MRS Hot Cell Cask Handling Area ....................... 2.4

2.4 MRS Hot Cell Disassembly and Consolidation Area ............ 2.5

3.1 Average Turnaround Time Versus Unit Train Size for a Repository Shipping Cask ........................... 3.7

A.1 Flow Chart of MRS/Repository Transportation Simulation Model .... A.2

A.2 Flow Chart of the MRS Shipping Cask Handling System Simulation Model .................................. A.3

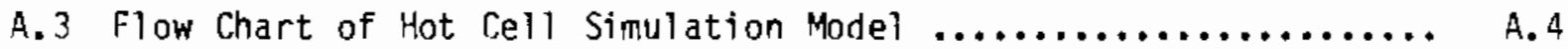




\section{TABLES}

3.1 MRS to Repository Shipping Cask Capacity Assumptions .......... 3.2

3.2 Estimates of Process Time for Handing Transportation

Casks at MRS Facility ............................... 3.3

3.3 Minimum Shipping Cask Turnaround Time $\ldots \ldots \ldots \ldots \ldots \ldots \ldots \ldots \ldots . \ldots \ldots$

3.4 Maximum Spent Fuel Assembly Lag Storage Requirements ......... 3.8

3.5 Use of MRS Spent Fuel Handling Equipment Based on a 365-Day 0perating Year .............................. 3.10

3.6 Reliability Analysis of Hot Cell Process Steps Occurring in the Disassembly Area .............................. 3.11

3.7 Summary of Disassembly Station Area Availability Requirements ... 3.12

3.8 Comparison of Annual Shipping Casks Required for Alternative Truck/Rail Sptits ................................ 3.13

3.9 Impact on Expected MRS Facility Performance of Variations in Truck/Rail Split ................................. 3.14

3.10 Impact of Reduced Shipping Cask Capacities on MRS Facility Performance............................. 3.15

3.11 Breakdown of Spent Fuel Assembly Types................... 3.16

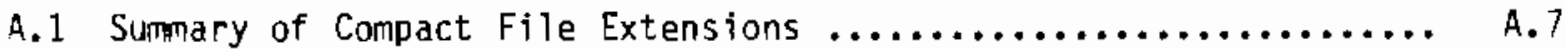

B.1 Calculation for a Single Crane 20-Ton Crane ................. B.1 


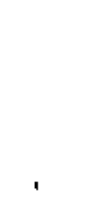




\subsection{INTROOUCTION}

The Pacific Northwest Laboratory (PNL) has completed a performance evaluation of the proposed monitored retrievable storage (MRS) facility. This performance assessment was undertaken as part of the PNL Monitored Retrievable Storage Program sponsored by the Department of Energy (OOE).

The primary goal of the study was to determine whether the conceptual MRS facility would have adequate capability to process spent fuel at the specified design rate of 3600 metric tons of uranium (MTU) per year. The proposed MRS facility is designed to receive, consolidate, and, when needed, temporarily store spent fuel from U.S. commercial nuclear power plants. At some future time the spent fuel will be retrieved from temporary storage and shipped to a repository where it will be permanently stored. The general layout of the MRS facility is shown in Figure 1.1. As it arrives at the MRS facility, spent fuel will be routed to the receiving and handling (R\&H) building. In the R\&H building the spent fuel will be removed from its shipping cask and transferred to the hot cell. The spent fuel will be disassembled, consolidated and canistered for temporary storage and eventual transport to the repository.

To assess the adequacy of the facility design, three specific simulation analysis computer models were developed. Each model was designed to address a different aspect of the facility operation. The documentation for these three design evaluation models and the assessment of the throughput performance of the MRS facility conceptual design (as of March 1985) are presented in this report.

\subsection{MRS FACILITY PERFORMANCE MEASURES}

Evaluation of the MRS conceptual design covered two general areas:

1) evaluating the facility's expected throughput performance based on design criteria; and 2) assessing the facility's ability to handle variations in the arrival of spent fuel.

To evaluate the facility's throughput performance, design drawings and process time estimates were analyzed to obtain performance estimates based on 


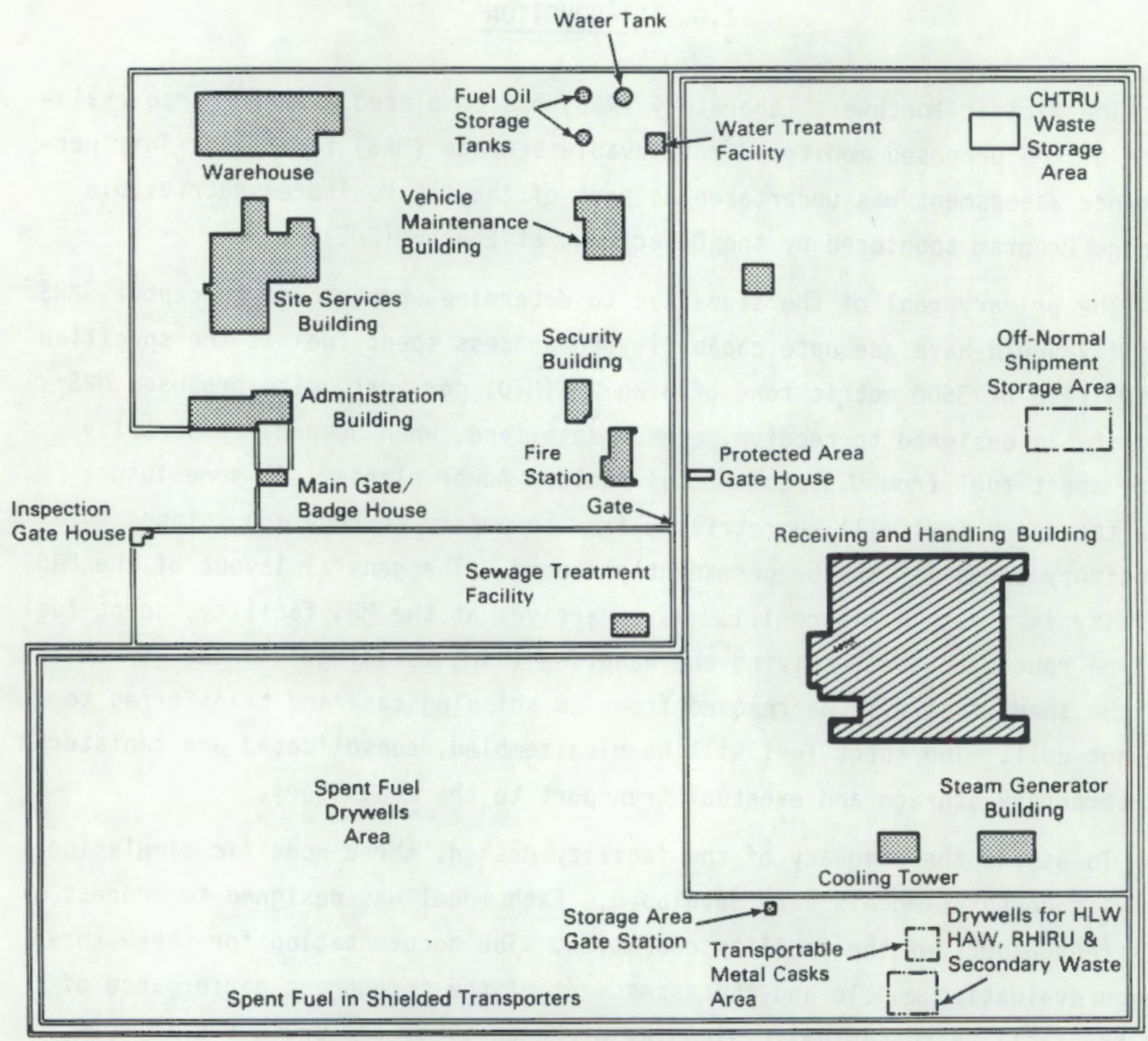

R\&H Building Included in Performance Assessment

\section{FIGURE 1.1. MRS Facility Layout}

design specifications. The base case of the performance evaluation was developed from stated assumptions regarding factors such as:

- shipping cask turnaround time

- adequacy of lag storage capacities

- equipment requirements (availability and reliability)

- excess capability for processing spent fuel. 
Shipping cask turnaround time is a base case performance measure because cask handling operations at the MRS facility will interface with the rest of the federal nuclear waste management system. Smooth functioning of this interface will facilitate processing operations at the MRS facility; the result is a steady flow of spent nuclear fuel for processing and a waste transportation system that operates smoothly without unnecessary delays in cask availability.

The adequacy of lag storage capacities is a second performance measure of the base case. By compensating for surges in the arrival of spent fuel, adequate lag storage capacity helps ensure the smooth flow of material through the facility. The most important lag storage area is the hot cell front-end lag storage, which provides space for spent fuel assemblies (SFAs) that have been removed from shipping casks and are awaiting disassembly. Front-end lag storage reduces cask turnaround time by eliminating delays in cask unloading. Reduced cask turnaround time in turn reduces cask fleet requirements.

A third performance measure of the base case design is the expected availability and reliability of major equipment. By obtaining and reviewing estimates of equipment use, the constraints or bottlenecks in throughput capability can be identified. Also, once equipment use has been determined, the amount of time each equipment component must be available to meet throughput requirements can be caiculated. Equipment availability requirements can then be used to determine minimum equipment reliability requirements.

A fourth performance measure is an estimate of the facility's capacity to process fuel beyond the design requirement. The estimate of supplemental processing capability provides a measure of the facility's ability to handle increased processing requirements, surges in the arrival of spent fuel, and extended unscheduled outages.

To assess the ability of the proposed facility to handle variations in the arrival of spent fuel, we evaluated such factors as:

- variations in the amount of spent fuel received by truck and by rail

- capacities of aiternative shipping casks

- arrival of different types of spent fuel assemblies. 
The ability of the facility to handle variations in the arrival pattern of spent fuel is a measure of the flexibility of the design. For example, at the time of this analysis, the design assumption was that half of all spent fuel would arrive by truck and half by rail. A larger percentage of fuel arriving by truck casks, which contain less spent fuel than rail casks, results in a larger number of shipping casks to be received and handled. Our analysis sought 1) to determine if the cask handling capacity of the facility was adequate to deal with casks of differing types and capacities, and 2) to measure the impact of these variations on facility performance.

Another measure of design flexibility is the facility's performance in handling various types of spent fuel assemblies. Twenty-five different fuel assembly designs by five designers and six vendors have been produced. Many of these designs are different enough to require a tool changeover in disassembly and consolidation equipment before the SFA can be processed. These tool changeovers halt disassembly and consolidation for as long as one or two shifts each. In this analysis, we sought to measure the impact of these tool changeovers on material flow. In addition, ways to alleviate the impact of these tool changeovers (e.g., campaigning fuel types, dedicated cells, etc.) were analyzed.

\subsection{ANALYSIS OVERVIEW}

A description of the performance assessment methodology and a brief summary of the proposed MRS R\&H facility design data are presented in Chapter 2. The design data are based on the Parsons/Westinghouse configuration with four hot cells, and operating assumptions are those presented in the functional design criteria (FDC) for an integrated MRS facility. (a) The results of the performance assessment are presented in Chapter 3.

(a) Pacific Northwest Laboratory. March 1985. Functional Design Criteria for an Integrated Monitored Retrievable Storage (MRS) Facility, Revision 3. MRS-3-85, Pacific Northwest Laboratory, Richland. 


\subsection{PERFORMANCE ASSESSMENT METHODOLOGY}

The performance of the MRS facility was assessed using a computer model to simulate facility operation. The MRS facility and the modeling technique used for the analysis are described in this chapter.

\subsection{FACILITY DESCRIPTION}

The general layout of the MRS facility based on the conceptual design (Parsons 1985) is shown in Figure 1.1. The layout consists of a receiving and handling (R\&H) building, a spent fuel storage area, and support facilities. An overview of the MRS R\&H building is provided in Figure 2.1, and a cutaway diagram of the building is shown in Figure 2.2. A diagram of the cask handling area of each hot cell is shown in Figure 2.3.

Spent fuel arrives at the MRS facility in shipping casks transported by either truck or rail. Following inspection and washdown, casks are transported to the R\&H building. An overhead crane lifts them from the transport vehicle and places them on a cart for transport to the cask unloading room. Inside the cask unloading room, the spent fuel assemblies (SFAs) are lifted from the shipping cask and placed inside the disassembly and consolidation area of a hot cell.

A single fuel assembly being removed from the shipping cask is shown in Figure 2.4. The disassembly station can hold three pressurized water reactor (PWR) assemblies or seven boiling water reactor (BWR) assemblies (Parsons 1985). If the disassembly station is full, SFAs can be placed in lag storage, provided adequate storage space exists. The lag storage area for SFAs is shown with the lid open in Figure 2.4. As the disassembly station is available, the SFAs are disassembled, consolidated, and canistered; canistered fuel rods are placed in canister lag storage. These canisters will eventually be put in concrete storage casks and taken to be emplaced in storage. When shipment to the repository occurs, canisters will be removed from the MRS storage yard and placed into repository shipping casks. 


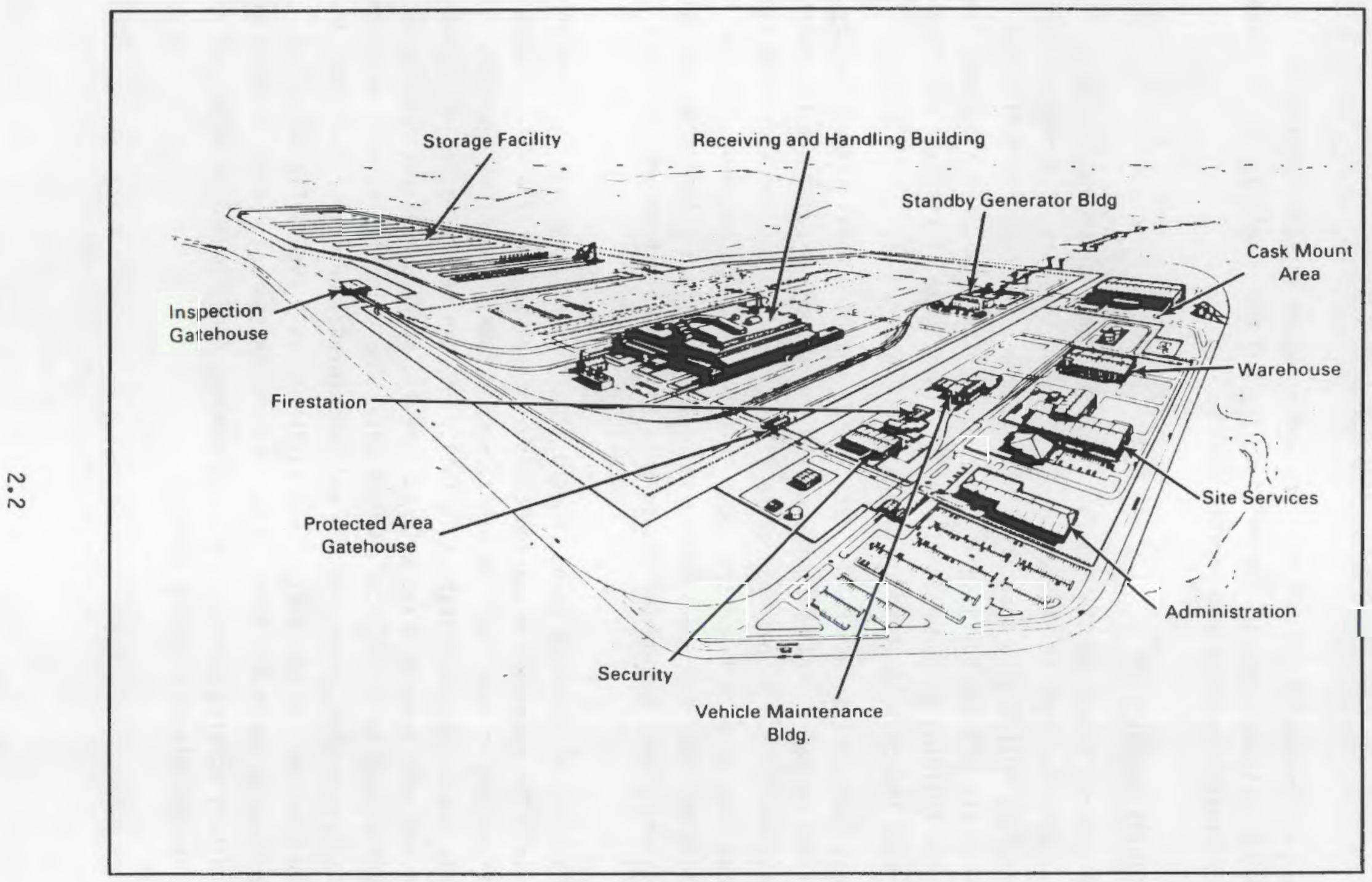

FIGURE 2.1. Integral Monitored Retrievable Storage Facility (Parsons 1985) 


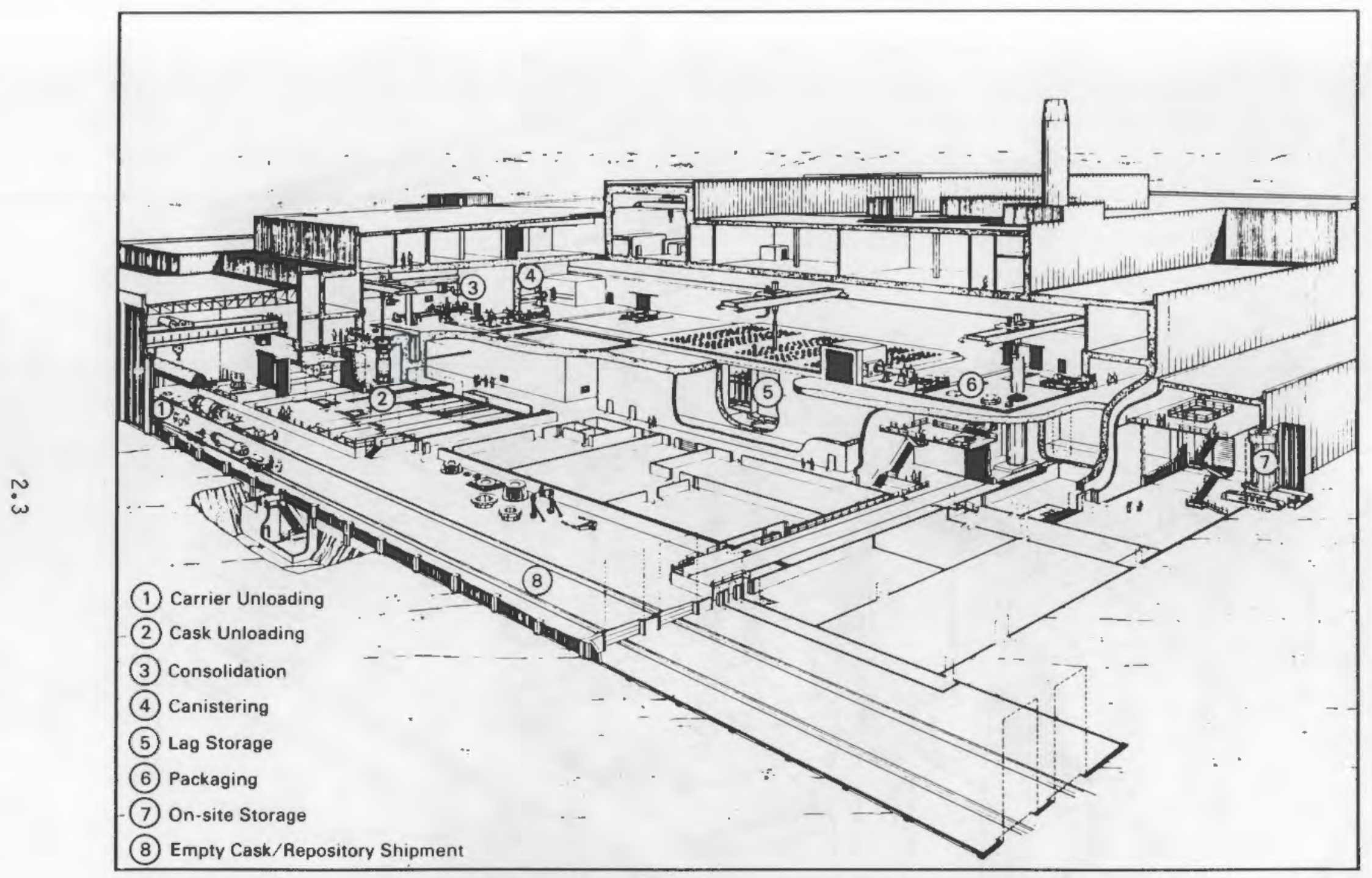

FIGURE 2.2. MRS Receiving and Handling Ruilding (Parsons 1985) 


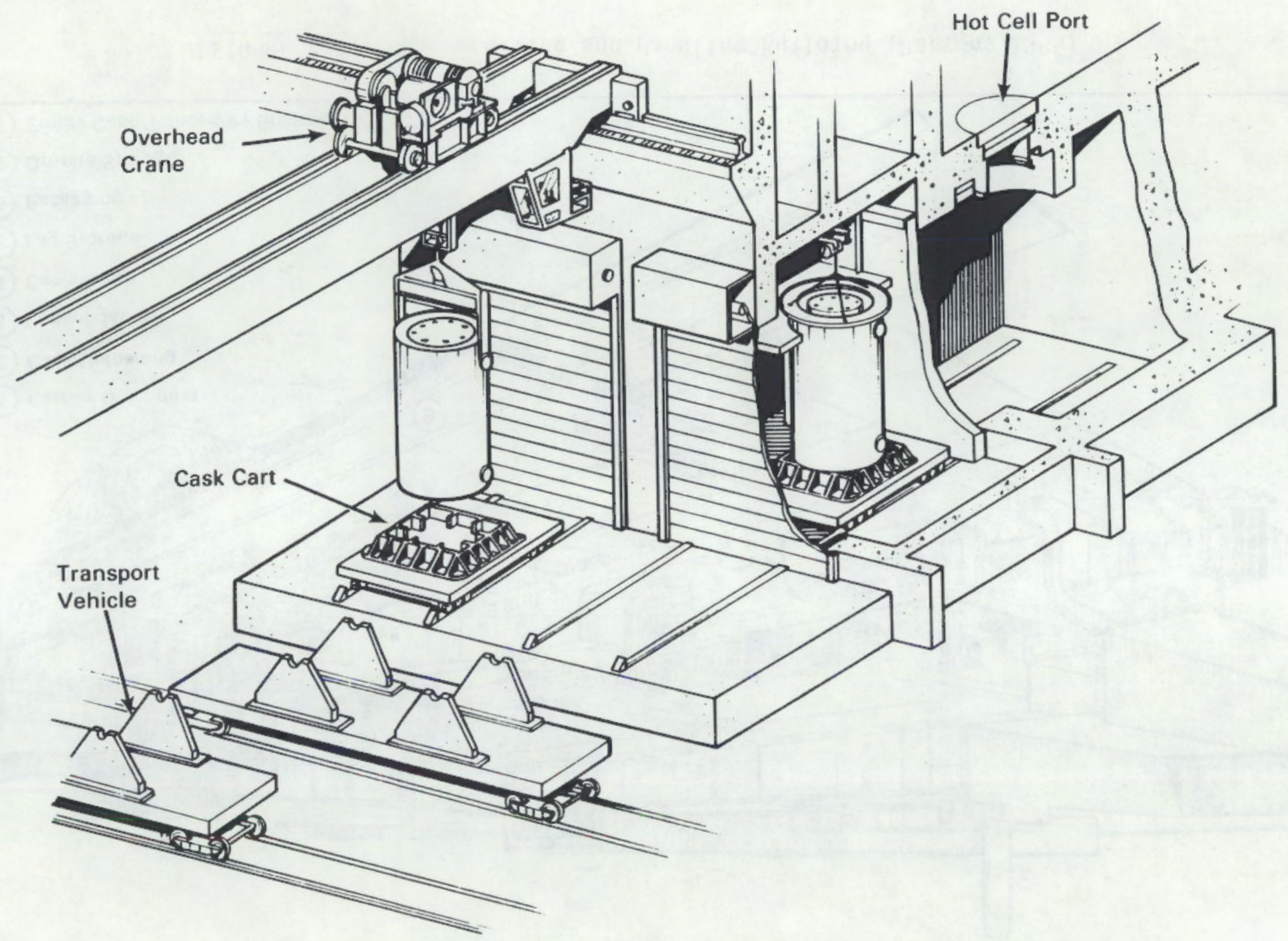

FIGURE 2.3. MRS Hot Cell Cask Handling Area (Parsons 1985) 


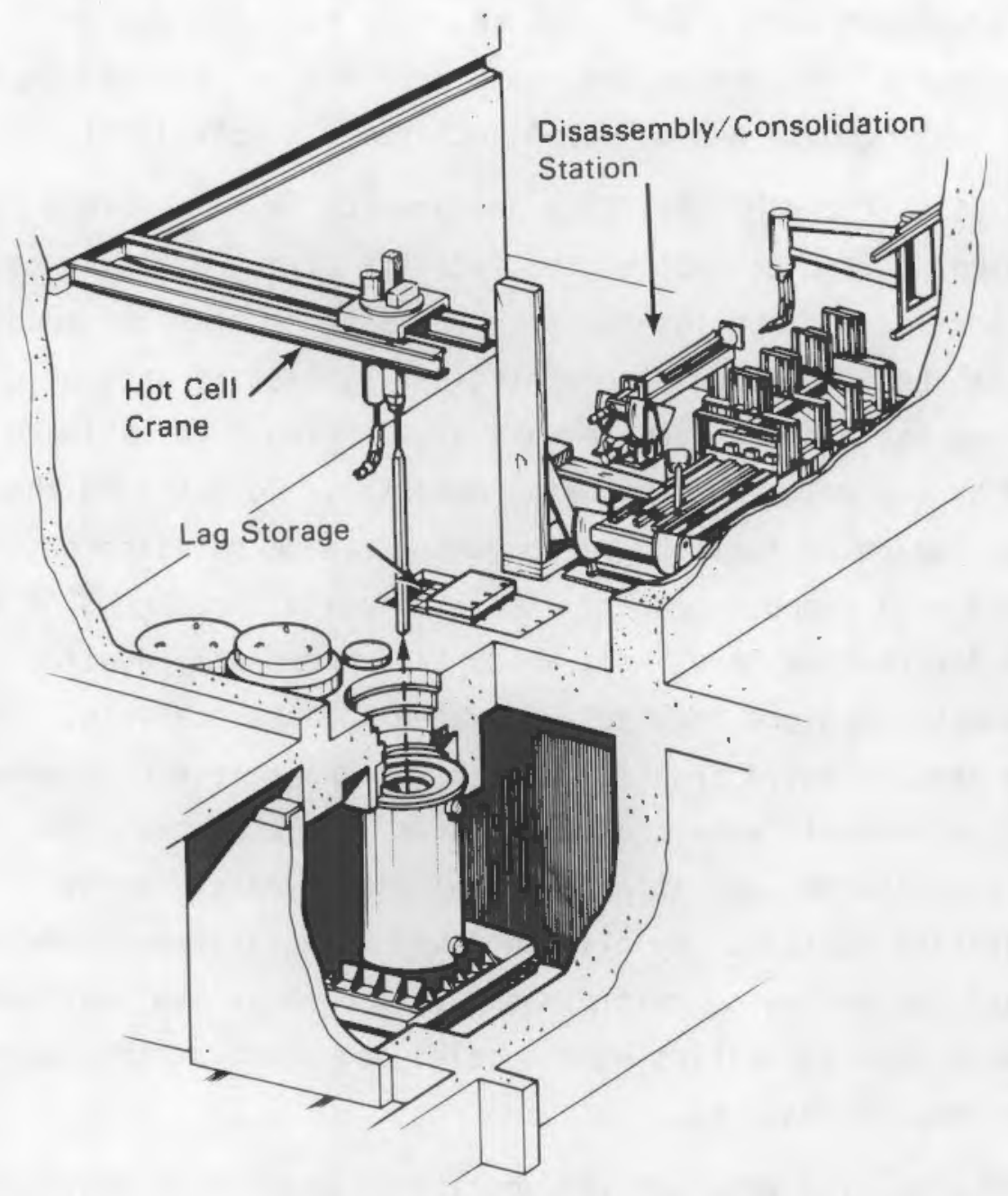

FIGURE 2.4. MRS Hot Cell Disassembly and Consolidation Area (Parsons 1985)

\subsection{APPROACH}

The approach used to assess the MRS R\&H facility performance involved two principal operations. The first was to analyze the facility design layout and processing time information provided by the architect and engineering firm that designed the facility. The second operation was to analyze the expected performance of the proposed MRS facility.

The conceptual design was developed by Ralph M. Parsons Company of Delaware with Westinghouse Electric Corporation subcontracted to produce the R\&H facility process and layout design. The results presented in Chapter 3 of 
this report are based on the Westinghouse, four hot cell design (Parsons 1985). Estimates of processing time were provided by Parsons Company in association with Westinghouse and Golder Associates (Parsons 1985).

The analysis of the MRS facility performance is complicated by the random nature of shipping cask arrival at the facility (i.e., shipping casks cannot be expected to arrive at fixed intervals). Performance measures such as equipment utilization can be calculated deterministically; factors such as cask turnaround time and lag storage requirements are difficult to estimate because they are affected by any delay in processing material. To estimate these delays and the resulting impact on facility performance, random shipping cask arrivals were simulated by a computer model. The simulation language SLAM (Simulation Language for Alternative Modeling), which is commercially available for the IBM PC and PC-compatible microcomputers, was used for the analysis. SLAM network symbols were used to build graphical models of MRS receiving and handling operations; these models were then translated into computer code. This code was used to simulate MRS operations on a minute-by-minute basis for two- to six-year operating periods. By altering SLAM input statements representing truck and rail car arrivals, multiple shipping cask arrival patterns and alternative shipping cask capacities were modeled and the expected impact on IRS facility performance measured.

The SLAM code also provided the ability to model both scheduled and unscheduled downtime for facilities and equipment. Downtime was modeled by having scheduled downtime occur at fixed intervals and unscheduled downtime occur randomly with a stated frequency (e.g., three failures per year, etc.). As new process time estimates and revised facility configurations were obtained, the model was easily revised and expected facility performance reevaluated.

This approach was used to evaluate a number of MRS facility designs and rekised process time estimates, e.g., the initial or preconceptual design (Kaiser 1984); some interim designs; and the Westinghouse, four hot cell design. The design evaluation models are discussed in the following section. 


\subsection{DESIGN EVALUIATION MODELS}

The performance evaluation of the MRS facility conceptual design was based on three models collectively referred to as COMPACT (Computer Optimization Model of Processing and Cask Transport). Fach model was designed to represent a different level of detail for a facility operation, depending upon which aspect was being evaluated. The three performance models developed in the performance assessment of the MRS facility design were:

- internal hot cell performance model

- transportation cask handling performance model

- MRS facility/repository performance model.

Activities included in the internal hot cell performance model were disassembly, consolidation, and canistering of spent fuel. This model was used to evaluate the expected perfomance of internal hot cell equipment and to identify front-end hot cell lag storage requirements.

The performance model of transportation cask handling at the MRS facility included all activities related to transportation casks, from their arrival, loaded, at the MRS receiving gate through unloading, decontamination and discharge. The cask handling performance model was used to evaluate the expected performance of cask handing equipment and to estimate expected cask turnaround time.

The MRS facility/repository performance model represents the interface between the waste transport operation and the waste processing operation. This model was used to assess the impact of MRS facility performance on the cask fleet requirements for the MRS/repository waste transportation system.

A description of model operation and software and hardware equipment requirements is contained in Appendix $A$. The performance assessment of the facility design obtained from these models is presented in Chapter 3. 
,

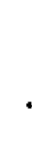




\subsection{ASSESSMENT OF MRS FACILITY PERFORMANCE}

The assessment of MRS facility performance was based on the Parsons/West. inghouse design for a four hot cell R\&H building. The three performance models described in Section 2.3 were used in measuring equipment utilization, lag storage requirements, and cask turnaround times.

\subsection{FACILITY OPERATING ASSUMPTIONS}

Assumptions included in the assessment of MRS facility performance were based on the functional design criteria (FDC) for an integrated MRS facility, Revision 3, tated March 1985. The assumptions are listed below and in Table 3.1:

- spent fuel arrives at a rate of 3600 metric tons of uranium (MTIJ) per year

- $60 \%$ (by weight) is PWR spent fuel

- $40 \%$ (by weight) is BWR spent fuel

- 0.462 MTU per PWR spent fuel assembly

- 0.186 MTU per BWR spent fuel assembly

- $50 \%$ (by weight) of spent fuel shipped by truck

- $50 \%$ (by weight) of spent fuel shipped by rail

- truck shipping cask capacity - 2 PWR spent fuel assemblies, or - 5 BWR spent fuel assemblies

- rajl shipping cask capacity - 12 PWR spent fuel assemblies, or - 32 BWR spent fuel assemblies

- 365 day operating year (24 hour days)

- 4 hot cells available for receiving and handling spent fuel.

\subsection{EXPECTED FACILITY PERFORMANCE}

The assessment of the MRS facility performance was completed by simulating operations with the COMPACT models to estimate facility performance measures 
TABLE 3.1. MRS to Repository Shipping Cask Capacity Assumptions

\begin{tabular}{ccccc} 
Repository Type & $\begin{array}{c}\text { PWR Assemblies } \\
\text { Per Canister }\end{array}$ & $\begin{array}{c}\text { BWR Assemblies } \\
\text { Per Canister }\end{array}$ & $\begin{array}{c}\text { Canisters per } \\
\text { Shipping Cask }\end{array}$ \\
\cline { 2 - 4 } Basalt & 12 & 30 & 9 & 3 \\
Tuff & 4 & 14 & 7
\end{tabular}

such as shipping cask turnaround time and spent fuel handling throughput capability. The advantages of a simulation analysis are that varying throughput requirements and process times can be considered for various design concepts. Simulation analysis provides a performance assessment that could not have been obtained deterministically. Estimates of the R\&H building's expected performance, given the process times in Table 3.2 and the operating assumptions stated in Section 3.1, are presented in the following sections.

\subsubsection{Shipping Cask Turnaround Time}

Shipping cask turnaround time includes those operations from arrival of a shipping cask containing spent fuel assemblies until the empty and decontaminated cask is ready for shipment out from the MRS facility. The interface for both the reactor/MRS and the MRS/repository transportation systems was anaTyzed. Turnaround time was analyzed to determine if proposed cask handling facilities are adequate 1) to promptiy process casks to minimize delays, and 2) to provide a steady supply of spent fuel to the R\&H building hot cells and from the hot cell to the repository. The analysis of cask handling operations and turnaround times is also important since both will influence total costs of the waste transportation system. In particular, the size of the shipping cask fleet will be influenced by the time that each cask spends at the MRS facility.

Potential cask handling delays can occur in two areas. The first involves delays in the availability of washdown/cask handing equipment such as overhead cranes, cask carts, etc. The second potential delay is in the hot cell unloading room. Shipping casks cannot be unloaded until there is space in the hot cell lag storage or disassembly stations. In this analys is of cask turnaround time we assumed that adequate lag storage exists in the hot cell and looked 
TABLE 3.2. Estimates of Process Time for Handling Transportation Casks at MRS Facility (Parsons 1985)

Activity Description Receiving and Handling:

Positioning rail car and truck for inspection

Inspection through monitor portal unit

Inspection pit area under car and truck visual inspection

Inspection platform for top visual inspection

Transfer from gatehouse inspection to $R \& H$ washdown area

Disconnect and hook car up to puller units

Washdown - double pass action

Drying

Transfer from washdown area to cask handling area

Position cask transport vehicle for cask of $f$-loading

Remove cask tiedowns, impact limiters, and personnel barriers

Complete preparations for cask of f-loading

Position cask lifting yoke - rotate cask to vertical and place on cask cart

Remove cask valve covers - install gas sampling/venting system - take gas samples and vent cask - remove outer cask cover (if necessary) - install shield/contamination barrier adapter untorque inner closure bolts

Move cask (on cart) onto unloading cell; engage contamination barrier, close shadow shield and shield door

Remove cell entry port shield plugs and remove cask inner closure

Unload cask
Time Estimate, Minutes

\begin{tabular}{cc}
\hline Truck Cask & $\frac{\text { Raj Cask }}{5}$ \\
\hline$?$ & 5 \\
5 & 3 \\
5 & 10 \\
8 & 5 \\
5 & 8 \\
3 & 5 \\
$30-60$ & 6
\end{tabular}

14

16

10

15

45

60

20

30

35

95

120

20

20

30

40 
TABLE 3.2. (contd)

\begin{tabular}{|c|c|c|}
\hline Activity Description & \multicolumn{2}{|c|}{ Time Estimate, Minutes } \\
\hline Receiving and Handling: & Truck Cask & Rail Cask \\
\hline Unload cask & \multicolumn{2}{|c|}{$\begin{array}{l}5 \mathrm{~min} / \text { BWR fuel } \\
\text { assembly }\end{array}$} \\
\hline $\begin{array}{l}\text { Inspect cask - replace inner closure - } \\
\text { replace entry port shield plugs }\end{array}$ & 45 & 75 \\
\hline $\begin{array}{l}\text { Open shadow shield and shield door - } \\
\text { disengage contamination barrier - } \\
\text { move cask into decontamination area }\end{array}$ & 20 & 20 \\
\hline $\begin{array}{l}\text { Complete inner closure installation - } \\
\text { remove shield/barrier adapter - survey } \\
\text { for contamination - decon if necessary. } \\
\text { Replace outer cover (if necessary) }\end{array}$ & 120 & 150 \\
\hline $\begin{array}{l}\text { Move cask to transport vehicle and rotate } \\
\text { to horizonta! - remove lifting yoke }\end{array}$ & 35 & 35 \\
\hline $\begin{array}{l}\text { Install cask tiedowns, impact limiters, } \\
\text { personnel barriers, etc. }\end{array}$ & 45 & 60 \\
\hline Complete preparations for cask and & 20 & 30 \\
\hline Fuel Rod Consolidation: & $\begin{array}{l}3 \text { PWR Fuel } \\
\text { Assemblies }\end{array}$ & $\begin{array}{l}7 \text { BHR Fuel } \\
\text { Assemblies }\end{array}$ \\
\hline $\begin{array}{l}\text { Load fuel assemblies (if fuel assemblies are } \\
\text { in lag storage) }\end{array}$ & 45 & 105 \\
\hline Disassemble fue? & 150 & 325 \\
\hline Consolidate fuel rods & 70 & 95 \\
\hline Load fuel rods in canister & 15 & 15 \\
\hline Spent Fuel Encapsulation: & \multicolumn{2}{|c|}{$\begin{array}{l}\text { Time Estimate } \\
\text { Canister }\end{array}$} \\
\hline $\begin{array}{l}\text { Rotate canister and place in evacuation } \\
\text { chamber }\end{array}$ & \multicolumn{2}{|c|}{5 min } \\
\hline $\begin{array}{l}\text { Evacuate canister and backfill with inert } \\
\text { gas - weld closure lid }\end{array}$ & \multicolumn{2}{|c|}{$20 \min$} \\
\hline $\begin{array}{l}\text { Decontaminate and inspect (leak check and } \\
\text { ultrasonic exam of weld) }\end{array}$ & \multicolumn{2}{|c|}{95 min } \\
\hline $\begin{array}{l}\text { Survey canister for contamination - move } \\
\text { to lag storage cask, or to concrete cask }\end{array}$ & \multicolumn{2}{|c|}{$25 \min$} \\
\hline
\end{tabular}


only at delays caused by the unavallability of facilities or equipment. Lag storage capacity was analyzed separately and those results are presented in the next section.

The analysis of cask turnaround time was based on the facility operating assumptions stated in Section 3.1. Based on these assumptions, the annual volume of casks and the rate of their arrival from reactors to the MRS facility would be:

1169 PWR truck casks - 1 arrives each $7.5 \mathrm{hr}$

774 BWR truck casks - 1 arrives each $11.3 \mathrm{hr}$

195 PWR rail casks - 1 arrives each $44.9 \mathrm{hr}$

121 BWR rail casks - 1 arrives each $72.9 \mathrm{hr}$.

The minimum turnaround time for casks was calculated by summing estimated process times for cask handing activities (Table 3.2). Minimum turnaround times vary from 11.5 hours to 21.5 hours, depending on type of cask and spent fuel (Table 3.3).

TABLE 3.3. Minimum Shipping Cask Turnaround Time

\begin{tabular}{lc} 
Cask Type & $\begin{array}{c}\text { Minimum Achievable } \\
\text { Turnaround Time }\end{array}$ \\
\hline PWR Truck & $11.5 \mathrm{hr}$ \\
BWR Truck & $12.0 \mathrm{hr}$ \\
PWR Rail & $17.5 \mathrm{hr}$ \\
BWR Rail & $21.5 \mathrm{hr}$
\end{tabular}

The COMPACT model simulated random arrival of casks to the MRS facility. The average cask arrival rates corresponded to the rate necessary to meet throughput requirements. The availability of cask handling facilities/equipment (i.e., days per year facilities/equipment are operable) was varied from 365 days to 250 days per year to measure the impact on cask turnaround time. Typically, as facility availability decreased, processing delays occurred and turnaround time increased accordingly.

Results of the COMPACT simulation analysis indicate that expected cask turnaround time is approximately one hour longer than the minimum achievable 
turnaround time. Because of the large cask handiing capacity at the reactor/MRS interface, turnaround time did not significantly increase as the availability of cask handling facilities/equipment was reduced to 250 days per year.

Cask handling from the MRS facility to the repository was analyzed using the process times given in Table 3.2 for similar cask handling operations. Two hot cell exit ports were assumed to be available for unloading overpacked fuel canisters into rail casks for shipment to the repository. The assumptions regarding repository cask capacities are shown in Table 3.1 .

The number of casks per train shipment (i.e., unit train size) will affect cask turnaround time since larger trajns will result in casks waiting longer to be handled when a train arrives at the MRS loading ports. Average cask turnaround time versus unit train size for a 365-day loading year for the tuff and salt repository scenarios is shown in Figure 3.1. As train size increases from one to ten shipping casks, turnaround time at the MRS facility increases from 15 hours to 77 hours, respectively. Cask turnaround time for the basalt repository scenario is also shown in Figure 3.1, which shows MRS shipping cask turnaround time increasing from 17 hours to 83 hours as unit train size increases.

\subsubsection{Adequacy of Lag Storage Capacities}

The COMPACT model was used to review the adequacy of hot cell lag storage capacities. SFA lag storage is that storage area adjacent to the disassembly station in the hot cell where SFAs await disassembly, consolidation, and canistering. Canister lag storage is that storage area adjacent to the hot cell exit ports where canistered fuel is stored before it is placed into storage casks and moved on out to storage.

Lag storage serves as a buffer between unloaded shipping casks and the spent fuel disassembly operation. Insufficient lag storage capacity results in delays because casks cannot be unloaded until space becomes available. The simulation model was used to determine the maximum lag storage required if casks were to arrive randomly and if there were to be no cask unloading delays 


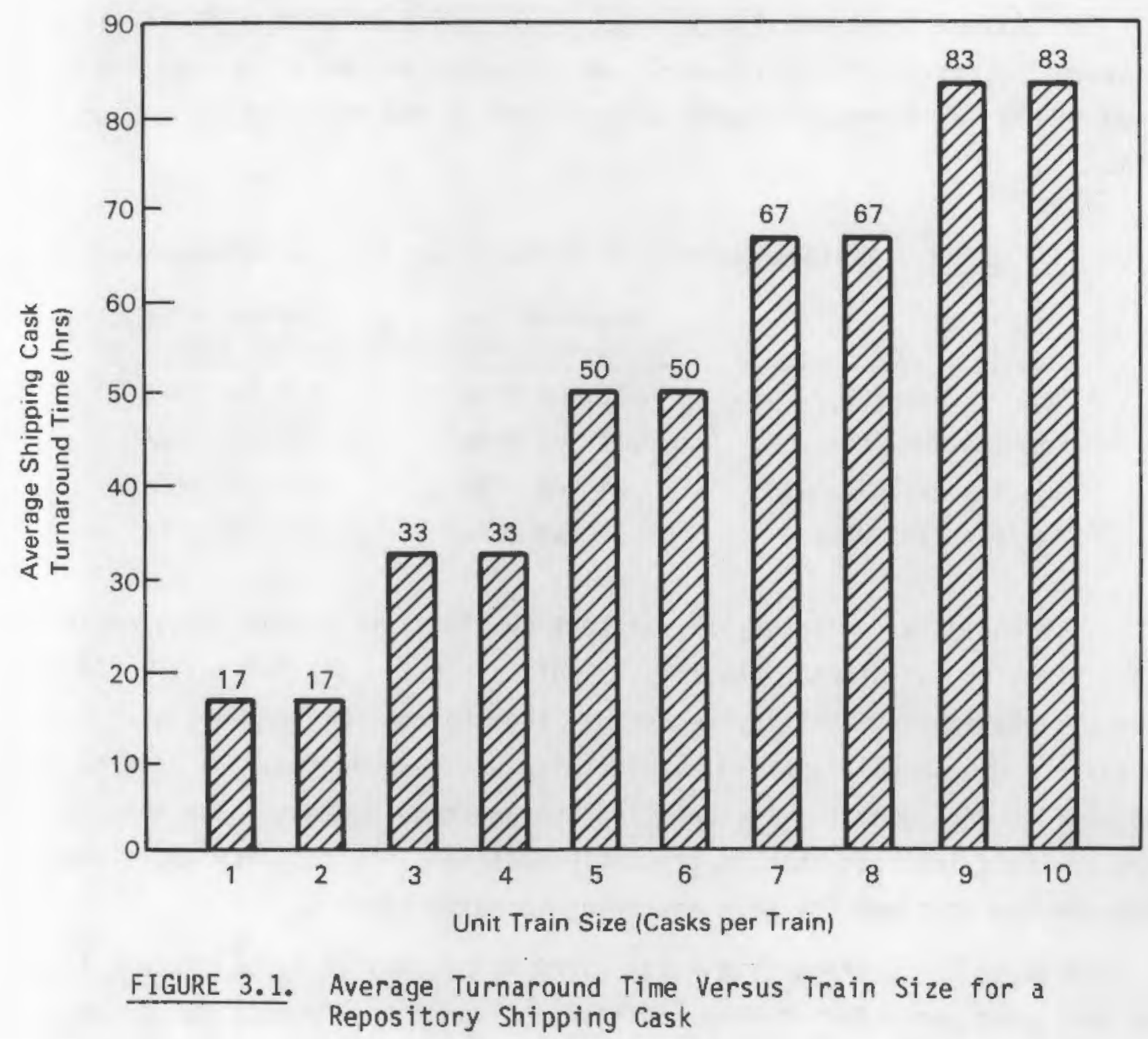

because of insufficient lag storage. It was assumed that hot cells would be dedicated to a particular type of spent fuel assembly to minimize the need for tool. changeovers. The following dedication of hot cells was assumed:

Hot cell 1 - BWR spent fuel (GE $7 \times 7$ assembly type)

Hot cell 2 - BWR spent fuel (mixed BWR assembly types)

Hot cell 3 - PWR spent fuel (Westinghouse $15 \times 15$ assembly type)

Hot cell 4 - PWR spent fuel (mixed PWR assembly types). 
The maximum front-end lag storage requirements at $100 \%$ availability of the disassembly station (365 days/year) are presented in Table 3.4, and are compared to the lag storage capacities specified by the MRS facility design prints.

TABLE 3.4. Maximum Spent Fuel Assembly Lag Storage Requirements

$\frac{\text { Hot Cell }}{\text { No. } 1 \text { - BWR (GE 7x7) }}$
No. 2 - BWR (Mixed)
No. 3 - PWR (W 15x15)
No. 4 - PWR (Mixed)

\author{
Required Lag \\ Storage Capacity \\ 112 BWR SFAs \\ 137 BWR SFAS \\ 34 PWR SFAS \\ 32 PWR SFAS
}

Designed Lag Storage Capacity

320 BWR SFAs

320 BWR SFAs

180 PWR SFAs

180 PWR SFAS

This analysis indicates that at $100 \%$ availability of the disassembly station, existing lag storage capacity is sufficient for all hot cells. As disassembly station availability decreases, lag storage requirements will increase. Disassembly station availability was reduced from 365 days to 250 per year to determine the increase lag storage requirements. The results of this analysis indicate that as presently designed, the facility would have adequate lag storages for each operating scenario tested.

Canister lag storage is a large (1000 MTU capacity) area adjacent to the hot cell exit ports for storing canisters of spent fuel rods. Requirements for canister lag storage depend on the operational mode of the MRS facility. There appear to be three basic operational modes for the MRS facility that should be reviewed for their impact on the canister storage capacity requirements:

- Flow-Through - Spent fuel is consolidated, canistered and shipped immediately directly to the repository.

- Arrivals Exceeding Shipments - The MRS facility must store material because material arriving has exceeded the receiving capability of the repository.

- No Repository Shipments - The repository is not prepared to receive material from the MRS facility. 
The MRS facility could experience each of the above phases of operation at some time. Idealiy, canister lag storage requirements for each phase should be examined and an optimal lag storage design selected based on the entire analysis. For example, the flow-through mode will require only minimal lag storage capacity since the lag storage only serves as a buffer to canister unloading operations. A reduced or delayed repository receiving capability will require the MRS facility to store material either internally in lag storage or externally in storage casks. A cost tradeoff analysis beyond the scope of this study could determine the optimal internal/external storage mix.

\subsubsection{Equipment Performance}

Equipment performance is measured hy the rate at which equipment must be used in order to meet throughput requirements. Equipment use rate determines both the constraints to expanded throughput capability and the equipment availability requirements. Once constraints to expanded throughput capability have been identified, the most critical equipment in the MRS spent fuel handling process has also been identified. Equipment falling in this category should be closely reviewed in terms of processing rates and reliability. Equipment availability requirements refer to the length of time equipment must be operable to meet throughput requirements. Availability requirements can be used to calculate the amount of downtime each piece of equipment can tolerate; this information can then be used to set reliability requirements.

Estimates of the use of key MRS spent fuel handling equipment obtained through simulation modeling are provided in Table 3.5. Similar to the analysis of $\mathrm{Tag}$ storage requirements, estimates of equipment use are based on the assumption that hot cells will be dedicated to particular types of spent fuel assemblies to minimize tool changeover requirements.

Based on the use rates presented in Table 3.5, the proposed disassembly stations have the highest potential to constrain MRS throughput capability: 1) the average use of disassembiy stations is the highest of any equipment $(50 \%)$, and 2) disassembly stations must be operated and maintained remotely and, thus, are vulnerable to reduced operating availability. 
TABLE 3.5. Use of MRS Spent Fuel Handling Equipment Based on a 365-Day Operating Year

\begin{tabular}{|c|c|c|}
\hline Equipment/Work Station & $\begin{array}{l}\text { of of Time } \\
\text { Equipment } \\
\text { is Used } \\
\end{array}$ & $\begin{array}{l}\text { Annual Avail- } \\
\text { ability Require- } \\
\text { ments (no. of days) }\end{array}$ \\
\hline Washdown Stations & 18 & 262 \\
\hline Carts (BWR Hot cells) & 24 & 88 \\
\hline Carts (PWR Hot cells) & 33 & 120 \\
\hline Overhead Crane (BWR Hot cells) & 12 & 44 \\
\hline Overhead Crane (PWR Hot cells) & 19 & 70 \\
\hline Disassembly Stations (BWR Hot celis) & 50 & 183 \\
\hline Disassembly Stations (PWR Hot cell) & 30 & 110 \\
\hline Consolidation Station (BWR Hot cell) & 12 & 44 \\
\hline Consolidation Station (PWR Hot cell) & 13 & 47 \\
\hline Welder (BWR Hot cells) & 25 & 91 \\
\hline Welder (PWR Hot cells) & 36 & 131 \\
\hline
\end{tabular}

There are three major factors that can contribute to disassembly station downtime that will, in turn, reduce operating availability:

- maintenance

- loss of worker productivity

- major decontamination.

Disassembly station downtime resulting from maintenance activities has been estimated by reviewing the expected reliability of hot cell components. Hot cell components are modular, and each module contains multiple components that can fait. Modules are changed out by remote removal and installation. Processes in the disassembly area of the hot cell that could contribute to disassembly station downtime were analyzed and results are presented in Table 3.6. An estimated 2034 hours of hot cell disassembly area downtime can be expected to result from equipment maintenance requirements.

Additional downtime in the hot cell disassembly area can be expected from major decontamination requirements and loss of worker productivity. Major decontamination requirements are estimated to be 480 hours per year and loss of 
TABLE 3.6. Reliability Analys is of Hot Cell Process Steps Occurring in the Disassembly Area

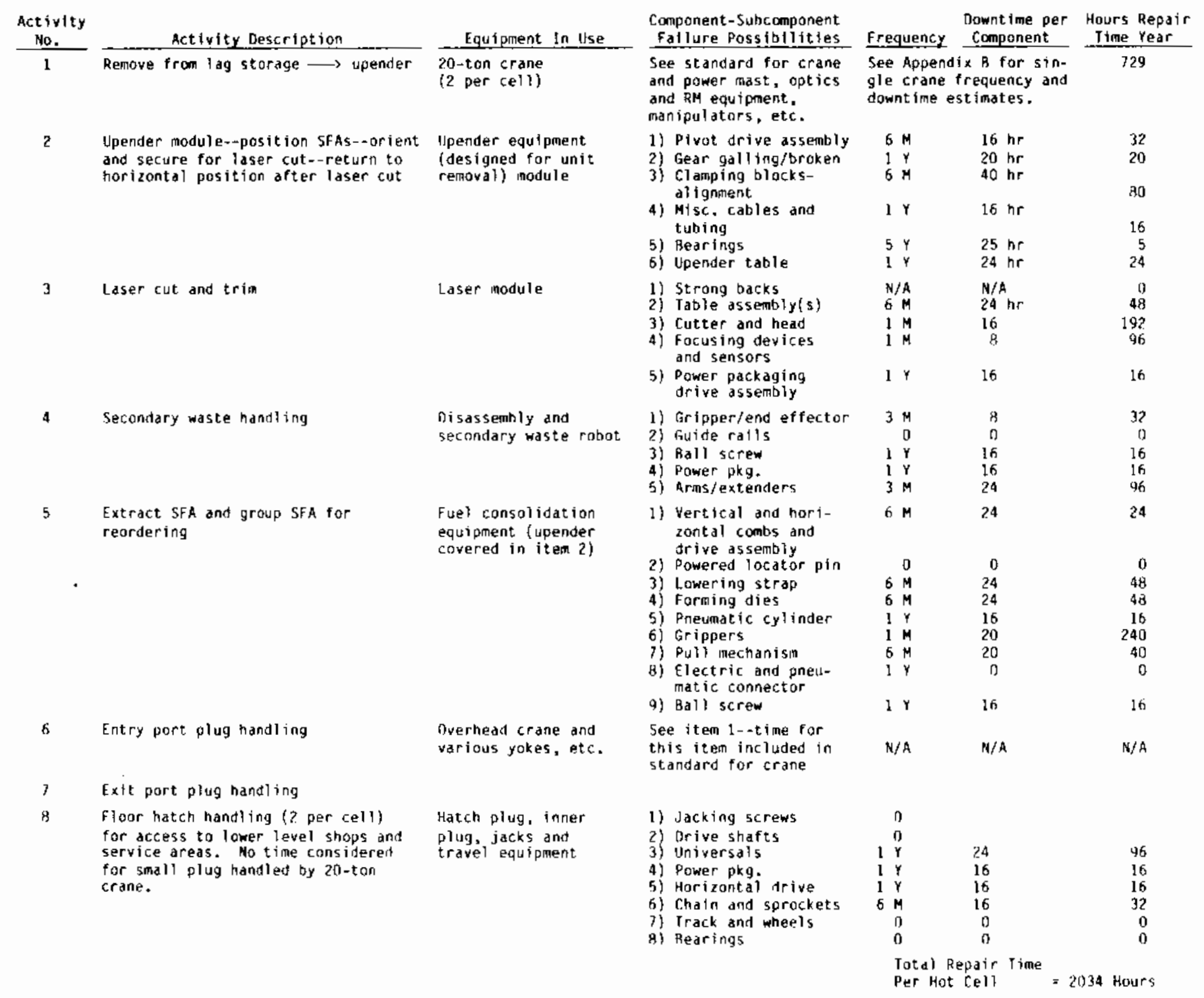


worker productivity is estimated to be 1 hour per shift (or 1095 hours per year). The total expected downtime per hot cell as a result of maintenance, decontamination, and loss of worker productivity is 3678 hours.

A summary of availability and downtime expected for disassembly station areas is provided in Table 3.7. Each of the two BWR hot cells will be either operating or in scheduled downtime 8030 hours per year, or $92 \%$ of the 8760 -hour operating year. This leaves 730 hours of slack time per BWR hot cell not accounted for. The two PWR hot cells are each expected to be operating or in scheduled downtime 6278 hours per year, or $72 \%$ of the 8760 -hour operating year. This leaves 2482 hours of slack time per PWR hot cell not accounted for. If BWR hot cell slack time is insufficient to meet throughput requirements, BWR spent fuel assemblies can be routed to PWR hot cells following a tool changeover in the PWR hot cell. Given this capability to equalize hot cell use, hot cell equipment is expected to be adequate to meet throughput requi rements.

TABLE 3.7. Summary of Disassembly Station Area Availability Requirements(a)

\begin{tabular}{|c|c|c|c|}
\hline $\begin{array}{l}\text { Disassembly } \\
\text { Station Area }\end{array}$ & $\begin{array}{l}\text { Availability } \\
\text { Requirements }\end{array}$ & $\begin{array}{l}\text { Expected } \\
\text { Downtime }\end{array}$ & Tota 1 \\
\hline BWR hot cells & $4392 \mathrm{hr} / \mathrm{yr}$ & $3638 \mathrm{hr} / \mathrm{yr}$ & $8030 \mathrm{hr} / \mathrm{yr}$ \\
\hline PINR hot cells & $2640 \mathrm{hr} / \mathrm{yr}$ & $3638 \mathrm{hr} / \mathrm{yr}$ & $6278 \mathrm{hr} / \mathrm{yr}$ \\
\hline
\end{tabular}

(a) An $8760-\mathrm{hr}$ maximum is based on the assumption that the hot cell will operate $24 \mathrm{hr} /$ day, $365 \mathrm{days} / \mathrm{yr}$.

\subsubsection{Throughput Capability}

The functional design criteria state that the MRS facility shall have adequate redundancy and surge capacity to meet the annual 3600 MTU processing requirement. Excess processing capability will enable the facility to handle fluctuations in the totals of spent fuel shipped yearly and would also enable the facility to recover from an extended unscheduled outage. Using the base case assumptions (shown in Section 3.1) and varying only the amount of spent fuel arriving at the facility each year, the maximum throughput capability of the MRS facility was identified. The maximum throughput is that amount of 
spent fuel that can be processed without a large increase in cask turnaround cime or in the number of backlogged casks. Assuming optimal use of each of the four hot cells and taking into consideration expected hot cell downtime, the maximum instantaneous throughput capability of the MRS facility is estimated to be approximately 4800 MTU per year. This represents a surge capacity $30 \%$ above the designed processing rate.

\subsection{IMPACT OF VARIATIONS IN ARRIVAL PATTERNS ON FACILITY PERFORMANCE}

An important measure of the effectiveness of the MRS facility design is the ability of the facility to meet throughput requirements given potential variations in operating conditions. Accordingly, the impact of variable operating conditions on R\&H facility performance was analyzed. In each of the following sections, the impact on facility operations of changes in one of the primary base case assumptions is examined.

\subsubsection{Variations in Truck/Rail Split}

At the time of the analysis one of the MRS facility design assumptions was that $50 \%$ (by weight) of the spent fuel would arrive by truck and $50 \%$ would arrive by rail. Because rail casks have higher capacity, fewer casks would be needed to meet throughput requirements. Also, rail casks are more efficient because the bulk of cask handling time is spent preparing casks for unloading or shipment out. The number of casks required to meet the 3600 MTU per year throughput requirement for alternative truck/rail splits is shown in Table 3.8.

TABLE 3.8 Comparison of Annual Shipping Casks Required for Alternative Truck/Rail Splits (3600 MTU/yr)

\begin{tabular}{|c|c|c|c|c|}
\hline & Truck & Casks & Rail & Casks \\
\hline Scenario & $\overline{B W R}$ & PWR & BWR & $\overline{P W R}$ \\
\hline All Truck & 1548 & 2338 & -- & $\rightarrow$ \\
\hline \multicolumn{5}{|l|}{$50 / 50$} \\
\hline \multicolumn{5}{|l|}{ Truck } \\
\hline Rail & 774 & 1169 & 121 & 195 \\
\hline All Truck & $\rightarrow$ & - & 242 & 390 \\
\hline
\end{tabular}


COMPACT was used to estimate the impact of alternative truck/rail splits on expected MRS facility performance; that analysis is summarized in Table 3.9. This analysis shows that cask turnaround time does not significantly increase as the percentage of fuel shipped by truck increases. The insensitivity of cask turnaround times to truck/rail split is attributed to the cask handing capacity incorporated in the facility design. At the worst case scenario of $100 \%$ truck shipments, all cask handing facilities/equipment are in use only $60 \%$ of the time or Tess.

\subsubsection{Alternative Cask Capacities}

Similar to the truck/rail split, cask capacity affects the number of casks required to meet throughput requirements. As cask capacities decrease, the number of casks the MRS facility must handle increases. The functional design criteria specify the following cask capacities:

- 2 PWR SFAs per truck cask

- 5 bur sfas per truck cask

- 12 phr sfas per rail cask

- 32 bWR SFAs per rail cask.

These are the cask capacities specified in the base case assumptions, and as previously stated, the MRS facility is adequate to handle the volume of casks resulting from these capacities. To measure the adequacy of MRS cask handling equipment, the expected performance of the MRS facility was assessed assuming significantly smaller cask capacities. These cask capacities are the same initially used to evaluate the preconceptual MRS facility design (before

TABLE 3.9. Impact on Expected MRS Facility Performance of Variations in Truck/Rail Split

Cask Turnaround

$\frac{\text { Scenario }}{100 \% \text { Truck }} \frac{\text { Time }(\mathrm{hr})}{\frac{\text { BWR }}{13.3} \frac{\text { PWR }}{12.8}}$

$50 / 50$

Rail

Truck

$100 \%$ Rail
$12.6 \quad 12.0$

$22.0 \quad 18.0$

$22.0 \quad 18.0$
Facilities/Equipment Use

$\frac{\text { Washdown }}{30.0 \%} \frac{\text { Overhead Crane }}{\frac{B W R}{20 \%}} \frac{\frac{\text { PWR }}{32 \%}}{\frac{\text { BWR }}{35 \%}} \frac{\text { PWR }}{52 \%}$

$18.0 \%$

$12 \% \quad 19 \%$

$24 \% \quad 33 \%$

$5.5 \%$

$3 \% \quad 5 \%$

$11 \% \quad 14 \%$ 
larger capacity new generation casks were assumed for the analysis). The impact of reduced shipping cask capacities on MRS facility performance is presented in Table 3.10. Shipping cask turnaround time is not significantly different for the smaller capacity casks, but use of cask handling equipment is doubled as a result of the increased number of casks. Even with the reduced cask capacities, throughput requirements can still be met because the MRS facility has been designed with an excess cask handling capacity.

\section{TABLE 3.10. Impact of Reduced Shipping Cask Capacities on MRS Facility Performance}

\begin{tabular}{|c|c|c|c|c|c|c|c|}
\hline \multirow{2}{*}{ Cask Capacities } & \multirow{2}{*}{$\begin{array}{c}\text { Average } \\
\text { around } \\
\end{array}$} & \multirow{2}{*}{$\begin{array}{l}\text { Cask Turn- } \\
\text { Time (hr) } \\
\end{array}$} & \multicolumn{3}{|c|}{ Facilities/Equipment } & \multicolumn{2}{|l|}{ Use } \\
\hline & & & & Overhea & Crane & Cask & Carts \\
\hline & oush & & D & 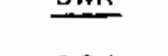 & & & \\
\hline $\begin{array}{l}\text { Truck: 2 PWR/5 BWR } \\
\text { Raj1: } 12 \text { PWR } / 32 \text { BWR }\end{array}$ & 12.3 & 20.0 & $18 \%$ & $12 \%$ & $19 \%$ & $24 \%$ & $33 \%$ \\
\hline $\begin{array}{l}\text { Truck: } 1 \text { PWR/2 BWR } \\
\text { Rail: } 7 \text { PWR /18 BWR }\end{array}$ & 13.8 & 19.3 & $38 \%$ & $29 \%$ & $39 \%$ & $48 \%$ & $60 \%$ \\
\hline
\end{tabular}

\subsubsection{Arrival of Different Types of Spent Fuel Assemblies}

Disassembly equipment is designed to process particular types of spent fuel assemblies. Each hot cell can receive and process a variety of spent fuel assembly types, however, a tool changeover is required. For example, before a hot cell tooled to disassemble and consolidate PWR Westinghouse $15 \times 15$ type spent fuel assemblies could receive and process BWR General Electric $7 \times 7$ type assemblies, a tool changeover of 8 to 16 hours would be required in the assembly/consolidation area.

The different types of spent fuel assemblies that could be arriving at the MRS facility were reviewed and their arrival was simulated to determine if adequate time for tool changeover exists. The PNL design team reviewed the available 1983 spent fuel data base to develop a breakdown of existing types of spent fuel assemblies (shown in Table 3.11). As previously stated, a probable operating scenario is to dedicate one hot cell to Westinghouse $15 \times 15$ spent fuel assemblies, one hot cell to General Electric $7 \times 7$ spent fuel assemblies, and the two remaining hot cells to PWR and BWR spent fuel assemblies. The worst case 

TABLE 3.11 Breakdown of Spent Fuel Assembly Types (based on
available 1983 spent fuel data) (a)

\begin{tabular}{|c|c|c|c|}
\hline Vendor & Type & $\begin{array}{c}\text { No. of } \\
\text { Assemblies }\end{array}$ & $\begin{array}{l}\text { \% of Total } \\
\text { As semblies }\end{array}$ \\
\hline & & & PWR \\
\hline Westinghouse & $17 \times 17$ & 1,216 & $11 \%$ \\
\hline Westinghouse & $15 \times 15$ & 4,941 & $44 \%$ \\
\hline B\&W & $15 \times 15$ & 2,466 & $22 \%$ \\
\hline B\&W (PII) & $14 \times 14$ & 404 & $4 \%$ \\
\hline CE & $16 \times 16$ & 168 & $2 \%$ \\
\hline CE & $14 \times 14$ & 1,477 & $13 \%$ \\
\hline CE (Palisades) & $15 \times 15$ & 477 & $4 \%$ \\
\hline & & & BWR \\
\hline GE (Dresden 1) & $6 \times 6$ & 685 & $2 \%$ \\
\hline $\mathrm{GE}$ & $7 \times 7$ & 16,624 & $58 \%$ \\
\hline GE & $8 \times 8$ & 10,995 & $38 \%$ \\
\hline $\mathrm{GE} / \mathrm{EX}$ (BRP) & $9 \times 9$ & 152 & $1 \%$ \\
\hline$A C / E X$ (LAC) & $10 \times 10$ & 228 & $1 \%$ \\
\hline
\end{tabular}

(a) Information obtained from R. I. Smith, Pacific Northwest Laboratory, May 1985.

scenario is that varying types of spent fuel assemblies will arrive randomiy from the reactors. Assuming that the equivalent of one rail cask of any one type of spent fuel assembly will be accumulated before disassembly stations are changed over to process (or campaign) a different assembly type, 318 tool changeovers are required. Assuming slack times shown in Table 3.7 are available for tool changeovers, a maximum of 400 tool changeovers could be completed. Our analysis showed that there is sufficient hot cell processing capability to meet tool changeover and throughput requirements. 
APPENDIX A

MODEL DESCRIPTION AND REQUIREMENTS 
MODEL DESCRIPTION AND REQUIREMENTS

\section{HARDWARE REQUIREMENTS}

An IBM-PC and the COMPACT (Computer Optimization Model of Processing and Cask Transport) model were used to simulate MRS facility operations. For this application, the PC requires at least $272 \mathrm{~K}$ of internal memory and at least one floppy disc drive.

SOFTWARE REQUIREMENTS/DESCRIPTION

The COMPACT model uses three software packages. They are listed below, with the minimum required version and the version of the software actually used.

\begin{tabular}{|c|c|c|}
\hline Package & Version Required & Version Used \\
\hline MS DOS (operating system) & 2.0 & 2.0 \\
\hline MS (Microsoft) FORTRAN & 3.13 & 3.2 \\
\hline SLAM-I I PC & --- & 2.0 \\
\hline
\end{tabular}

SLAM II PC is a personal computer version of the SLAM (Simulation Language for Alternative Modeling) simulation software. The SLAM II PC package required that the MS DOS operating environment be used, and also specified that if the option to include FORTRAN subroutines in SLAM models was exercised, the MS FORTRAN compiler was to be used. This requirement led to the use of MS FORTRAN Version 3.2 for the FORTRAN subroutines described later in this appendix.

SLAM II PC is a product of Pritsker \& Associates, InC. MS DOS and MS FORTRAN are products of the Microsoft Corporation.

Model/Software Description

The COMPACT model consists of SLAM input statements and FORTRAN subroutines. These were executed within the SLAM II PC environment to produce the 
results described and analyzed in the body of this report. Flow chart representations of the compact-simulation models are shown in Figures A.l

through A.3.

The performance model of the MRS/repository transportation system is represented by the flow chart shown in Figure A.1. In this flow chart, an initial rail cask fleet is created and routed to the MRS facility. At the MRS facility, empty rail casks wait to be loaded with overpacked canisters at the first available MRS loading port. The model assumes that two ports are avail. able for canister loading. Following loading, the rail casks accumulate at the MRS facility until a sufficient number of loaded rail casks are available to constitute a unit train shipment. Since unit train size for the MRS/repository transportation system has not yet been determined, an assumption of from one to ten rail casks per train was used. Once a unit train of loaded rail casks is

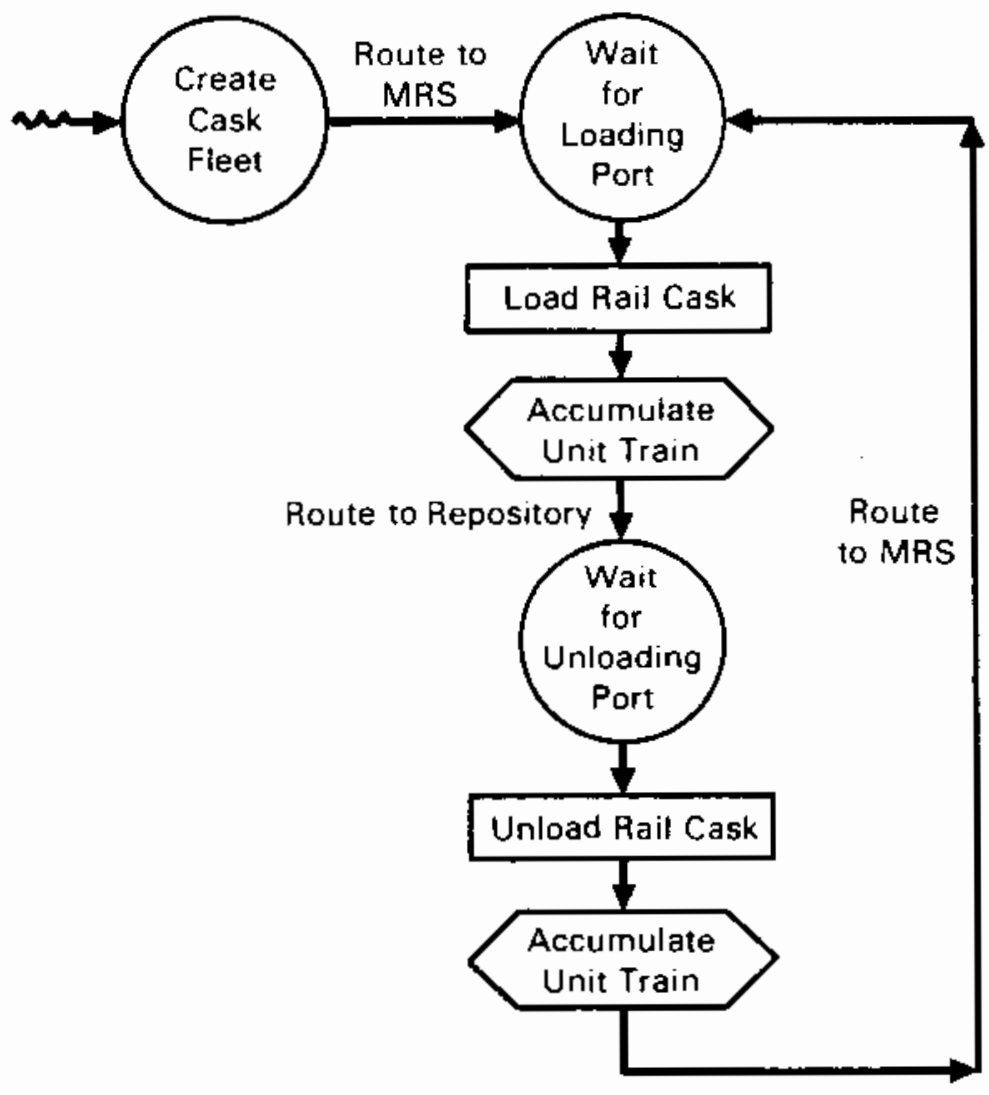

FIGURE A.1. Flow Chart of MRS/Repository Transportation Simulation Model 


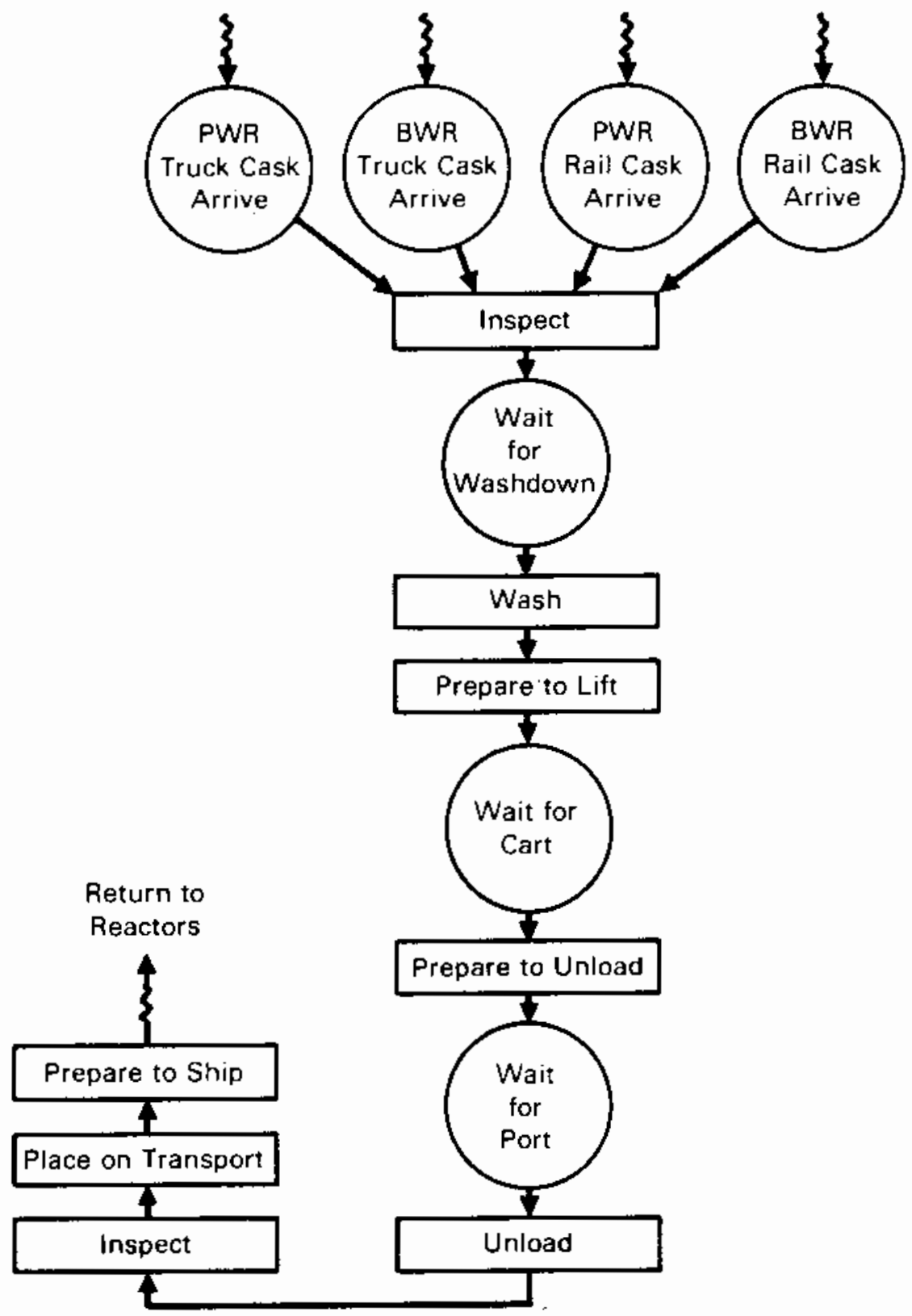

FIGURE A.2. Flow Chart of the MRS Shipping Cask Handling System Simulation Model

completed, the train is routed to the repository where it waits for an available repository unloading port. The model assumes two repository rail cask unloading parts at the repository. After they are unloaded, rail casks are routed back to the MRS facility when a unit train of unloaded rail casks has been accumulated. 


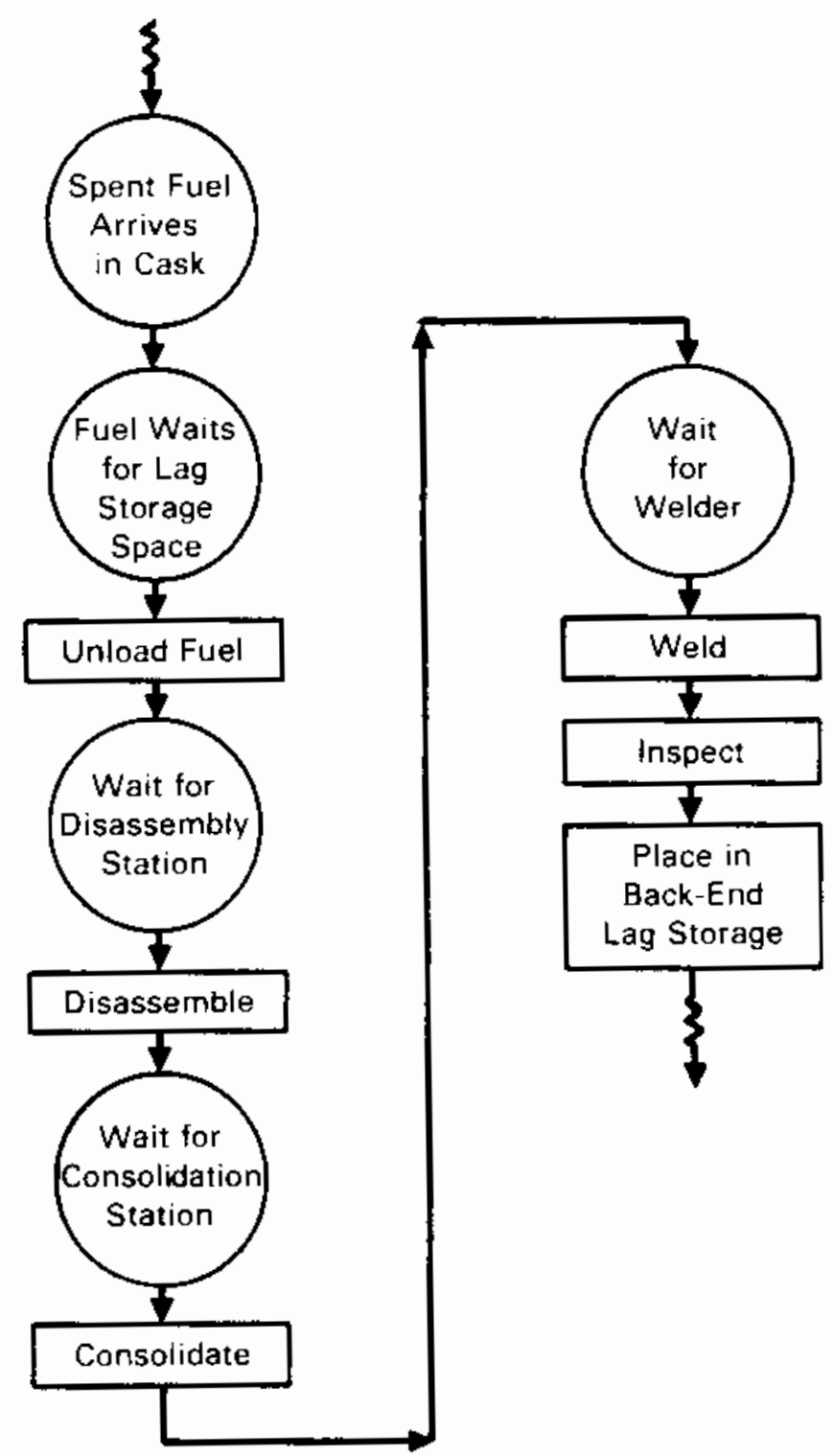

FIGURE A.3. Flow Chart of Hot Cell Simulation Model

A flow chart of the model of MRS shipping cask handling is shown in Figure A.2. Shipping casks arrive at the MRS facility from commercial reactors by truck and rail and are inspected. Following inspection, the casks are routed to a washdown facility and then on to the MRS cask receiving and handling area. Casks are prepared for removal from the transport vehicle and placed on a hot-cell cask cart when a cart (and overhead crane for lifting) becomes available. Each of the four hot cells is served by two cask cart lines. When 
it has been prepared for unloading, the cask waits for an available unloading port. When a port becomes available, spent fuel assemblies are removed and the emptied cask is inspected and decontaminated. The cask is then placed on a transport vehicle and returned to the waste transportation system.

The flow chart for the simulation model of internal hot cell operations is shown in Figure A.3. Spent fuel assemblies contained in shipping casks can be placed into the hot cell when sufficient space exists in the front-end hot cell lag storage or if the disassembiy station is idle. Once inside the hot cell, spent fuel assemblies are disassembled and consolidated in groups of three PWR or seven BWR spent fuel assemblies. After disassembly and consolidation operations are completed, the spent fuel is placed into canisters that are then welded and inspected. Finished canisters are then placed into back-end lag storage to await shipment to a repository.

The SLAM input statements are the means by which a model is communicated to SLAM. By changing the input statements, one can analyze changes in model parameters such as cask capacity, amount of waste accepted, etc. For this model a master file of input statements was maintained as CASK.DAT. A text editor was used to change input statements, therehy altering model parameters, as needed. In this way, CASK.DAT can be used to model any of the three facets of COMPACT: internal hot cell performance, shipping cask handling, or MRS/repository performance.

Changes to the model are made to CREATE statements which specify the different entities that are to exist in the system (here, the MRS facility). There are several CREATE statements among the model input statements. Any of them can be changed to prevent entities from being created, to reduce or create more entities, to vary the amount of time between their arrival into the system, and to change the time at which the entities begin arriving into the system. A more detailed description of SLAM input statements can be found in the book An Introduction to Simulation and SLAM (Pritsker and Pegden 1979).

The second element of the COMPACT model consists of two FORTRAN subroutines. The first routine, SFA, converts cask entities into spent fuel assembly entities, and is used in modeling internal hot cell performance. The second, UNIT, converts unit train entities to cask entities upon their arrival 
at the MRS facility, and recombines the casks into unit trains when they leave. UNIT is used to analyze the performance of the MRS facility/repository interface. These subroutines link with the SLAM II PC execution module to create the program MAIN. Changes in SLAM input statements do not necessitate recompilation of the subroutine, unless the model is being altered from hot cell to MRS/repository analysis (SFA to UNIT subroutines) or back again.

This appendix concludes with the procedure followed for running SLAM II PC and the MRS facility model, and a list of files used by SLAM II PC and COMPACT. Further details of developing and running SLAM II PC models can be found in the SLAM II PC User's Manual (Lilegdon and O'Reilly 1984).

1. To alter the SLAM input statements, copy the file CASK. BAT to another file with the file extension to .DAT. Use a text editor to make any desired changes to the SLAM input statements. When changes are completed, the new. DAT file should he copied or moved to Drive $B$ if necessary. Drive $B$ should also be selected as the logged disk drive. Insert the disk containing the SLAM Input Processor in Drive A. To translate the SLAM input statements into SLAM-readable code, type

\section{A: INPUT}

from the B drive. You will be prompted for the name of the model file you wish to translate; enter the name of the .DAT file. The results of the translation are placed in file with the same name as the input statement file and a file extension of .TRA.

2. To run the translated file, place the disk with the file MAIN.EXE (compiled SLAM code and subroutine) in Drive A. From Drive B, type

\section{A:MAIN}

The MAIN program asks for the name of the translation file to use. Enter the name of the .TRA file. The simulation will be performed. 
When it is completed, you are prompted for a file in which to place output statistics. Enter a file name with a .OUT extension.

3. To access output data, insert the SLAM Output Processor disk in Drive $A$, and type

\section{A: OUTPUT}

Enter the name of the .OUT file you wish to analyze, then choose a report option from the SLAM Report MENU.

To view model results an the screen, choose the screen as the report output type, look at the file, press return to go back to the Report Menu, then exit from the output processor (Option 12).

To print model results, choose the file output type and enter a file name for the report(s) (use a .RPT extension). When the menu is redisplayed, exit from the output processor and print the file with the CTRL-PRTSC printer toggle and the DOS "TYPE" command, or with a print utility program.

\section{TABLE A.1. Summary of Compact File Extensions}

\begin{tabular}{|c|c|}
\hline File Extension & Contents \\
\hline. .DAT & SLAM input statements \\
\hline . TRA & translated model \\
\hline $.0 U T$ & output data \\
\hline.$R P T$ & output report \\
\hline
\end{tabular}

A. 7 
APPENDIX B

QVERHEAD CRANE RELIABILITY ANAL YSIS 
TABLE R.1. Calculation for a Single Crane 20-Ton Crane

\begin{tabular}{|c|c|c|c|c|}
\hline Component Failure Possibilities & $\begin{array}{c}\text { Time } \\
\text { Between } \\
\text { Occurences }\end{array}$ & $\begin{array}{l}\text { Downtime per } \\
\text { Component (hr) } \\
\end{array}$ & $\begin{array}{l}1 \mathrm{Yr} \text { Prorate } \\
\text { if Frequency } \\
\text { is }>1 \text { Year (hr) }\end{array}$ & $\begin{array}{l}\text { Annual Time } \\
\text { Iotal (hr) }\end{array}$ \\
\hline 1. Major breakdown or planned overhaul (PM) & $5 Y$ & 168 & 34 & 34 \\
\hline 3. Cable wear & $2 Y$ & 72 & 36 & 36 \\
\hline 4. Break slips/locks & $1 Y$ & 24 & -- & 24 \\
\hline 6. Motor problems & $5 Y$ & 48 & 10 & 10 \\
\hline 7. Travel malfunction & $5 Y$ & 168 & 34 & 34 \\
\hline 8. Ways or structure danage & $10 Y$ & 336 & 34 & 34 \\
\hline 9. Drum wear & $5 Y$ & 72 & 16 & 16 \\
\hline 10. Power supply & $5 Y$ & 8 & 2 & 2 \\
\hline 14. Lights & $1 M$ & 4 & - & 48 \\
\hline $\begin{array}{l}\text { 15. Inspections: } 0 S H A \text {, third party, other } \\
\text { mandatory checks }\end{array}$ & $1 Y$ & 72 & -- & 72 \\
\hline 16. Each shift surveillance inspection & $8 \mathrm{hrs}$ & 0.2 & & 219 \\
\hline & $\begin{array}{l}365 \times 3= \\
1095 \text { checks }\end{array}$ & & & 729 \\
\hline
\end{tabular}




\section{REFERENCES}

Raymond Kaiser Engineers, Inc. 1984. Monitored Retrievable Storage Conceptual System Study: Dry Receiving and HandTing Facility. KEHR-83-96, issued by Kaiser Engineers Hanford Company, Richland, Washington.

Lilegdon, W. R. and J. J. O'Reilly. 1984. SLAM II PC Version User's Manual. Pritsker \& Associates, P.0. Box 2413, West Lafayette, Indiana 47906.

Ralph M. Parsons Co. 1985. Integral Monitored Retrievable Storage (MRS) Facility: Conceptual Design Report, Volumes I and IV. Report No. MRS 11, Ralph M. Parsons Co., Pasadena, California.

Pritsker, A. A. B., and C. D. Pegden. 1979. Introduction to Simulation and SLAM. Systems Publishing Corporation, P.0. Box 2161, West Lafayette, Indíana 47906. 


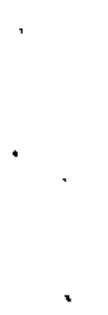




\section{DISTRIBUTION}

No. of

Copies

OFFSITE

6 B. C. Rusche

Office of Civilian Radioactive Waste Management

U.S. Department of Energy

RW-1

Washington, DC 20545

J. R. Hilley

Office of Civilian Radioactive Waste Management

U.S. Department of Energy

$\mathrm{R} W-30$

Washington, DC 20545

K. A. Klein

Office of Civilian Radioactive Waste Management

U.S. Department of Energy

RW-31

Washington, DC 20545

J. H. Carlson

Office of Civilian Radioactive Waste Management

U.S. Department of Energy

$\mathrm{RW}-32$

Washington, DC 20545

2 P. Gross

U.S. Department of Energy

Dak Ridge Operations Office

Oak Ridge, TN 37830

30 DOE Technical Information Center

Dorey Panno

Roy F. Weston, Inc. 2301 Research Blyd.

3rd Floor

Rockville, MD 20850
No. of

Copies

\author{
J. W. Voss \\ Golder Associates \\ 2950 Northup Way \\ Bellevue, WA 98004 \\ W. D. Woods \\ The Ralph M. Parsons Company \\ 100 West Walnut St. \\ Pasadena, CA 91124 \\ R. M. Jefferson \\ Sandia National Laboratories \\ Transportation Technology \\ Center \\ P.0. Box 5800 \\ Albuquerque, NM 87185 \\ G. C. Allen \\ Sandia National Laboratories \\ Transportation Technology \\ Center \\ P.0. Box 5800 \\ Albuquerque, NM 87185
}

ONSITE

3 DOE Richland Operations Office

R. D. Izatt (2)

R. B. Goranson

49 Pacific Northwest Laboratory

J. L. Braitman

A. D. Chockie (4)

J. F. Fletcher

J. J. Fuquay

R. M. Gale

R. J. Hall

$R$. $E$. Heineman

J. N. Holloway

G. M. Holter

C. J. Hostick (4)

C. H. Imhoff

D. S. Jackson 
No. of

Copies

H. S. Kelly

D. K. Kreid

M. R. Kreiter

R. C. Liikala

P. N. McDuffie

J. L. MCElroy

G. W. McNair

D. F. Newman

D. R. Payson

W. D. Richmond

R. E. Rhoads

L. C. Schmid
No. of

Copies

K. J. Schneider

M. J. Scott

R. L. Shaub

M. R. Shay

D. J. Silviera

A. L. Slavich

R. I. Smith

M. B. Triplett

C. M. Unruh

C. Winter (2)

T. W. Wood

Publishing Coordination $\mathrm{MH}$ (2)

Technical Information (5) 